\title{
The role of port cities and transnational municipal networks in efforts to reduce greenhouse gas emissions on land and at sea from shipping- an assessment of the World Ports Climate Initiative
}

Corresponding author: Paul Fenton, Tel: +46 13 286602, Fax: +46 13 281101, Email: paul.fenton@liu.se, Division of Environmental Technology \& Management, Linköping University, 58183 Linköping, Sweden

\begin{abstract}
In 2008, 55 of the world's largest ports voluntarily adopted the World Ports Climate Declaration (WPCD) and the International Association of Ports and Harbours committed to long-term work on implementation through the World Ports Climate Initiative (WPCI). This article assesses the work of WPCl since 2008 and makes five recommendations that, if implemented, could support efforts to reduce the climate and environmental impacts of port operations and international shipping. In particular, as the impetus for the WPCD came from a port city - Rotterdam - and their engagement with a transnational municipal network - the C40 Large Cities Climate Leadership Group - the paper considers the role of cities and transnational municipal networks in governance, and the potential for cities to play a more active and influential role in the maritime sector. The article presents an overview of literature on the role and function of transnational municipal networks, the background and development of the WPCD, analysis of the work of WPCl, and a discussion concerning the potential of cities and transnational municipal networks to support and add value to $\mathrm{WPCl}$ or similar initiatives in the maritime sector. This informs the conclusions and recommendations to marine policy-makers and port stakeholders.
\end{abstract}

\section{Keywords}

Ports; shipping; cities; transnational municipal networks; climate change; governance

This is a pre-publication version. The final version of this article has the DOI:

10.1016/j.marpol.2015.12.012 and is available at:

http://www.sciencedirect.com/science/article/pii/S0308597X15003826 


\section{Introduction}

Ports operate at the nexus of the world economy and are vital nodes in the countries and regions in which they are located, facilitating and enabling flows of information, materials, resources and peoples within countries, between countries, and across seas and oceans. Ports have traditionally been located in close proximity to urban areas and played an important role in the consolidation and growth of many port cities, not only in economic terms, but also with regard to culture, ideas and people. The urban life of port cities is often rich and unique in its character, contestations and diversity $[1,2,3,4]$

Whilst port operations have enriched - in multiple senses - the quality of life in many urban areas, ports also present challenges for the cities in which they are located, e.g. in terms of issues such as local air pollution from ships or inland transport, traffic and congestion, colocation of risky or polluting industrial facilities around ports. Such challenges interact with related urban dynamics and impact upon urban planning and other sectors, e.g. in terms of "upstream" investments in new infrastructure, changes to labour markets, or influxes of workers to informal settlements located in close proximity to ports $[1,5,6]$

The shifting, dynamic nature of such challenges means many problems are considered in isolation, as atomised, context-specific issues requiring local action and resolution. Nonetheless, some challenges have global implications and require the overcoming of barriers that create "first-mover" problems in multiple contexts. Few individual ports have the economic independence to refuse customers or dictate their terms to global markets when operating in isolation; the majority of ports are, to varying degrees, dependent on each other to solve complex, global challenges $[1,6]$.

Climate change is an example of an emerging global challenge with profound implications for ports, port cities and maritime transportation [7,8,9]. Climate change is a multi-faceted challenge, innately linked to the patterns of urbanisation, population growth and human impacts of the industrial age $[10,11]$. The complexity of mitigating and adapting to climate change has stimulated a diverse range of experiments in communities around the world $[12,13]$. Cities are often said to be at the forefront of the global fight against climate change, initiating actions for mitigation and adaptation that go beyond national targets [14].

Many ports and port cities, as well as other stakeholders, have joined or formed networks focusing on climate change and/or related topics, such as sustainable development (e.g. EcoPorts, ICLEI). Network governance through Transnational Municipal Networks (TMNs), it is assumed, provides opportunities for knowledge diffusion and capacity-building among diverse groups of stakeholders, whilst providing the opportunity for collective or synergetic actions, or the mobilisation or representation of common agendas. Becker et al. consider

This is a pre-publication version. The final version of this article has the DOI:

10.1016/j.marpol.2015.12.012 and is available at:

http://www.sciencedirect.com/science/article/pii/S0308597X15003826 
such collective, participatory enterprise essential for ports in the fight against climate change [15].

This paper explores the role of port cities and TMNs in efforts to reduce the climate and environmental impacts of shipping. To do so, the paper presents an overview of literature on TMNs, before presenting a case that emerged from port city involvement in a TMN - the World Ports Climate Declaration and World Ports Climate Initiative (WPCI). The development and implementation of WPCl is described and assessed with reference to literature on TMNs, in order to highlight challenges and opportunities for the $\mathrm{WPCl}$ and similar initiatives. These Results inform a Discussion and Conclusions proposing the need for stronger engagement of port cities and TMNs - in cooperation with ports, and stakeholders active in ports and shipping - to combat climate change and tackle other environmental problems.

\section{Literature review: Transnational Municipal Networks}

Climate change and the need for sustainable development are discussed in an extensive body of literature, much of which emphasises the role of municipalities as participating actors in multi-level governance $[16,17]$. In recent decades, various Transnational Municipal Networks (TMNs) have been formed to facilitate municipal work for sustainable development and, in recent years, such networks have given significant emphasis to efforts to mitigate and adapt to climate change $[18,19,20]$.

TMNs usually have multiple objectives and fulfil a range of roles, which Bouteligier categories as "(1) to exchange information, knowledge and best practices; (2) to increase cities' capacity; and (3) to voice cities' concerns in the international arena" [21]. Feldman offers a variation, stating "Networks perform three vital functions in regard to environmental problems: (1) generating and diffusing information; (2) undertaking effective policy evaluation strategies; and (3) initiating local response efforts without waiting for national efforts" (both formal and informal)" [13].

TMNs may be considered as "quasi-governmental" entities, with strong links to conventional, top-down models of government [22]; as flexible and dynamic alternatives to such hierarchies [21]; or as "governing from the middle" and mediating boundaries between other stakeholders [23]. TMNs may be global or regional in scope, addressing multiple or single themes, or be formed of specific categories or type of member (e.g. C40 Large Cities Group, Eurocities, Eurotowns). Typically, TMNs are associations to which member municipalities pay subscription fees in return for a range of services, including e.g. networking, knowledge transfer and capacity-building, the coordination of interests and

This is a pre-publication version. The final version of this article has the DOI:

10.1016/j.marpol.2015.12.012 and is available at:

http://www.sciencedirect.com/science/article/pii/S0308597X15003826 
representation in international processes such as the UNFCCC ${ }^{1}$, participation in events or projects, promotion or dissemination of information.

Hakelberg highlights the capacity of TMNs to enable "governance by diffusion" in an "increasingly fragmented, polycentric and transnational" system of global climate governance [24]. According to Feldman, the convening power of TMNs (as a platform and a forum) can "empower local levels of governance to develop the capacity to manage problems, prompting what we term "glocal" cooperation", with "broad diffusion of experience" an inevitable consequence [13]. In a similar vein, Giest and Howlett note that "TMNs are the institutional foundation for a concerted effort in climate change within and between countries", whilst recognising that TMNs provide added value when working in specific regions and with the support of national governments [25; see also 26]. In other words, TMNs may provide an opportunity to provide a framework for municipal climate change action, yet the framing context will influence the extent to which those frames are filled with content.

TMNs may thus provide a potential forum for coordination of interests, knowledge transfer, experimentation and other collaborative action concerning climate change. Despite this, TMNs are sometimes perceived as representing the "usual suspects" or as consolidating or over-emphasising particular types of cultural or institutional context, themes or solutions $[21,27,28]$. For example, Acuto [29] and Bouteligier [21] note the presence of a "coreperiphery" dynamic in the internal geography of the C40 Cities Climate Leadership Group, both in terms of representation, activity and thematic focus. McFarlane [30], Robinson [31], and Ward [32] note that certain categories of cities and municipalities tend to be overrepresented, or dominate, TMNs. A large group of cities are not represented or are underrepresented in TMNs. These "invisible cities" can be variously interpreted as being silenced in TMN agendas, less active than prominent TMN members, or in some cases, as "free riders".

Others challenge the supposed benefits of TMN activities to disseminate information and transfer knowledge. For example, Dolowitz et al. challenge proponents of "governance by diffusion" by contending that when moving from inspiration to implementation, U.S. municipalities tend not to draw upon international or high-profile examples. Rather, when identifying policies options, "instead of a directed and purposeful search occurring, leading to the best possible policy being borrowed... searches were less about best practice and more about convenience and perceptions of similarity" [33]. Posing the question "Why don't cities learn?" in a global study, Campbell suggests that in the best cases, "deliberate and

\footnotetext{
${ }^{1}$ For example, ICLEI - Local Governments for Sustainability plays a similar consultative role to the UN as the International Association of Ports and Harbours (IAPH).
}

This is a pre-publication version. The final version of this article has the DOI:

10.1016/j.marpol.2015.12.012 and is available at:

http://www.sciencedirect.com/science/article/pii/S0308597X15003826 
systematic" collection of hard and soft data occurs and facilitates municipal learning [34]. Thus, TMNs face the challenge of assisting the typical municipalities, as observed by Dolowitz et al., to achieve the best practice observed by Campbell. This may require a reconceptualisation of some TMN approaches or activities.

As previously noted, Giest and Howlett argued that the added value of TMNs is linked to the context in which they operate, and a regional (or continental) focus may facilitate action in certain contexts [25]. In the U.S. context, Krause suggests some municipal networks appear to have stronger leverage power or influence on their members' actions than others, albeit to a very limited extent. However, the "“leakage" of knowledge and norms" through publicly-available information may "may increase the average GHG relevant activities being taken by all cities, and in doing so, decrease the impact able to be attributed directly to membership" [35]. In other words, "free rider" municipalities may achieve as much or more as TMN members; however, this interesting question lies outside of the scope of this paper.

\section{Case: the World Ports Climate Declaration}

The previous section presented an overview of literature discussing the role of TMNs and their theoretical potential, as well as important criticisms and challenges. In the following section, the World Ports Climate Declaration is presented as a manifestation of activity to address the environmental and climate impacts of operations a global industry, ocean-going shipping. The WPCD was a city-led initiative, in which a TMN played an instrumental role; its background and development are described below.

\subsection{Background}

In 2006, the City of Rotterdam adopted a target to reduce the city's greenhouse gas emissions by $50 \%$ by 2030 , and the Rotterdam Climate Initiative (RCI) was established as a platform to initiate diverse activities in the city $[8,36]$. As the industries and operations in and around the Port of Rotterdam - Europe's largest port - were the main source of emissions in the urban area, $\mathrm{RCl}$ quickly focused attention on the port and related stakeholders. Other influences, such as recent changes to national legislation on transport emissions and ongoing legal challenges concerning the extension of the port, also influenced the context and highlighted the need for Rotterdam to adopt a systemic approach with a wide scope.

However, as a central node in the Dutch and European economy, any measures to reduce the environmental impacts of the port would have to be achieved without damaging the port's competitive status. This meant cooperation with other ports and stakeholders would be essential, as individual actions by a lone first-mover potentially risked generating negative

This is a pre-publication version. The final version of this article has the DOI:

10.1016/j.marpol.2015.12.012 and is available at:

http://www.sciencedirect.com/science/article/pii/S0308597X15003826 
socio-economic impacts, whilst moving environmental problems elsewhere. Other ports faced similar challenges, making collective action essential and win-win solutions desirable if ports were to effectively mitigate and adapt to climate change and other environmental problems.

With this in mind, Rotterdam approached the $\mathrm{C} 40$ and the Clinton Climate Initiative (CCl), requesting support in developing a programme for world ports to combat climate change, as well as in fostering political support in large port cities to address climate change. C40 was a relatively young TMN, created in 2005 by the then Mayor of London, Ken Livingstone. The network was formed of an invited group of the world's megacities and associate members representing municipalities at the forefront of efforts to combat climate change $[37,38,39]$. In 2006, C40 established a partnership with the William J. Clinton Foundation, a non-profit organisation, which had launched $\mathrm{CCl}$ to reduce the levels of and impacts of greenhouse gas emissions through work on cities, clean energy and forestry (Sovacool provides a longer discussion of $\mathrm{CCl}^{\prime}$ s role and activities [40]).

$\mathrm{CCl}$ was designated as the implementation partner of the $\mathrm{C} 40$ network [41]. In practice, this meant that the Cities Programme of $\mathrm{CCl}$ stationed City Directors in each of the $\mathrm{C} 40$ member cities and established "programme" teams to provide expertise and support to City Directors across different themes (e.g. waste management, lighting, building retrofits). This partnership aimed to increase the possibility for synergies, exchange and replication within the $\mathrm{C} 40$ network and thereby contribute to reducing greenhouse gas emissions both within the $\mathrm{C} 40$ cities and beyond $[29,37,42]$.

\subsection{Developing the World Ports Climate Conference}

Rotterdam and $\mathrm{C} 40-\mathrm{CCl}$ agreed to work together to develop the C40 World Ports Climate Conference and, in early 2007, established project teams to work on the initiative ${ }^{2}$. Rotterdam agreed to host two events, a preparatory conference and main conference. Together, Rotterdam, $\mathrm{C} 40-\mathrm{CCl}$ and participating stakeholders would co-develop an agenda for the two events and the principles of a practical, workable Declaration, around which a wider programme of activities could be structured. Rotterdam and $\mathrm{CCl}$ staff analysed the shipping industry, ports and cities in order to identify potential new approaches, methods and technologies that could reduce greenhouse gas emissions, improve local air quality and take into account other environmental considerations on land and at sea.

\footnotetext{
2 The author worked for CCl during 2007-8 and contributed to the development of the WPCD, but not to the subsequent implementation of the WPCl, which is described in "Results". As such, Section 3 of this paper is partly based on unreferenced source material from the author's own archive and personal recollections. This experience partly informs the author's analysis concerning what was expected during the WPCD development process and the outcomes of WPCI.
}

This is a pre-publication version. The final version of this article has the DOI: 10.1016/j.marpol.2015.12.012 and is available at: http://www.sciencedirect.com/science/article/pii/S0308597X15003826 
From an early stage, it was envisaged that the content of any programme would address clean ports (trans-shipments within the port area, sustainable transportation to and from the port), clean shipping (port policies for fairways, dock, etc; ship engines and fuels), and clean energy and industry $\left(\mathrm{CO}_{2}\right.$ sequestration, energy efficiency in industrial companies, reuse of industrial waste energy, biomass certification). Rotterdam informed C40 port cities and other important ports about the initiative and invited a select group to the preparatory conference, which was held on 25-27 November 2007. The preparatory conference provided an opportunity for port representatives to meet and informally discuss climate change and other challenges, paving the way for future collaborative work between port cities. Moreover, the preparatory conference provided an opportunity to present, discuss and agree upon a provisional draft of what would become the World Ports Climate Declaration [43].

The main objectives of the WPCD were defined as: exploring ways to reduce $\mathrm{CO}_{2}$ emissions from deep sea vessels calling at ports (i.e. ocean-going shipping); exploring ways to reduce $\mathrm{CO}_{2}$ emissions from port operations (i.e. terminal operations); exploring ways to reduce $\mathrm{CO}_{2}$ emissions from inland shipping and other modes of transport (i.e. logistic chains); exploring ways to promote the use of alternative energy sources (i.e. energy savings and renewables); and $\mathrm{CO}_{2}$ footprint calculation for ports (i.e. monitoring and policy evaluation). Opportunities for ports to work with biomass and carbon sequestration were to be also discussed as special topics at the main conference.

On 9-11 July 2008, representatives from many of the world's largest ports met in Rotterdam, together with a diverse range of stakeholders including shipping companies, shippers, terminal operators, fuel suppliers, logistics providers, environmental NGOs, service and equipment providers, etc. Cities were also represented, both directly, and also through the presence of $\mathrm{C} 40$ staff and $\mathrm{CCl}$ city directors and programme teams. The aforementioned topics were discussed in greater detail, with the conference culminating in the WPCD on behalf of conference participants to individually and jointly address climate change and reduce environmental impacts of shipping and port operations. The WPCD highlighted the potential of ports to influence supply chains and the opportunities to implement measures with additional co-benefits, whilst recognising the need for differentiation. By adopting the WPCD, ports indicated their intention to use the document to "guide action to combat global climate change and improve air quality" [44].

In order to facilitate implementation, steps had been taken to institutionalise the WPCD. During spring 2008, the Board of Directors of the International Association of Ports and Harbours (IAPH) adopted a resolution supporting the initiative and committing to long-term work on implementing the Declaration, with support tools including biannual conferences and a dedicated website $[5,44]$. Thus, when the Declaration was adopted by 55 ports in

This is a pre-publication version. The final version of this article has the DOI:

10.1016/j.marpol.2015.12.012 and is available at:

http://www.sciencedirect.com/science/article/pii/S0308597X15003826 
Rotterdam, the IAPH was ready to facilitate their interaction and develop working groups dedicated to specific topics and actions. This process - known as the World Ports Climate Initiative (WPCl) - was formally launched on 24-25 November 2008 in Los Angeles [5]. The progress of WPCl since its launch is discussed in the following section.

This is a pre-publication version. The final version of this article has the DOI: 10.1016/j.marpol.2015.12.012 and is available at:

http://www.sciencedirect.com/science/article/pii/S0308597X15003826 


\section{Results}

\subsection{WPCI: implementing the WPCD}

The WPCl focuses on five principal topics (ocean-going shipping; port operations; logistic chains; alternative energy; and environmental auditing $/ \mathrm{CO}_{2}$ inventories) and has led to specific initiatives between ports addressing e.g. intermodal transport, leasing agreements, cargo-handling equipment, LNG-fuelled vehicles, onshore power supply, and the clean shipping index. Moreover, the WPCl ports committed to increasing and strengthening support for its activities among the world ports community.

It is unclear to what extent this latter undertaking has been achieved. Nonetheless, several ports in the WPCl working groups have subsequently implemented measures with regard to particular topics (e.g. introduced hybrid cargo handling equipment), and also developed guidance documents and provided support to other ports attempting to begin work with such measures (e.g. concerning carbon footprinting or a toolbox for air quality and greenhouse gas emissions). Two examples are discussed here, the Environmental Ship Index and Onshore Power Supply:

\subsubsection{Environmental Ship Index (ESI)}

The ESI was the focus of significant attention during the process to develop the WPCD, and its continued development and increasing use represents one of the main achievements of the WPCl [1]. The basic idea was to develop a transparent system to improve the environmental performance of shipping. This would enable ports to incentivise accelerated adoption of cleaner shipping techniques, and shippers (and their customers) to introduce similar demands into their purchasing criteria, thereby increasing demand for clean shipping and influencing supply chains.

The ESI was established and is currently used by over 30 ports (mainly in Europe, but also in North America and Asia). The ESI is a voluntary system enabling automatic calculation of the environmental performance of ships' air pollutants and $\mathrm{CO}_{2}$ emissions. Ships reporting data through the system must achieve performance levels exceeding current international regulations and are eligible for discounted fees in ports. By April 2015, 3484 ships were registered in the system [45]

The ESI was partly inspired by the work of the Clean Cargo Group and its member companies $[46,47]$ and the Clean Shipping Project, a private governance initiative involving various companies in Sweden. Wuisan et al. identify factors enabling and constraining the Clean Shipping Project as relating to legitimacy, trust and robustness [48]. Wuisan et al. argue that the future development of the Clean Shipping Project and similar initiatives such as ESI is

This is a pre-publication version. The final version of this article has the DOI:

10.1016/j.marpol.2015.12.012 and is available at:

http://www.sciencedirect.com/science/article/pii/S0308597X15003826 
contingent on reaching a "critical mass" of membership, and improving the added-value, benefits and synergies offered, in order to expand reach across supply chains and thereby influence ocean-going shipping [48].

When planning the WPCD, it was hoped that it would be possible to align these and similar initiatives under the ESI umbrella, and link the ESI to real-time monitoring systems. Such monitoring would enable monitoring of ship performance at sea, and thus potentially enable shippers (and their customers) to formulate more specific demands concerning ship performance not just in port, but across the entire logistics chain, and link these to revolving funds aiming to finance investments in clean technologies (Gibbs et al. suggest this is critical [49]). However, it appears that these discussions have lost momentum and perhaps indicates the need for a mediator to facilitate and broker discussions; a TMN could potentially play such a mediatory role.

\subsubsection{Onshore Power Supply (OPS)}

OPS of electricity to ships at berth (also known as Alternative Maritime Power, Cold Ironing, Shoreside Electricity) was also the focus of considerable attention during the WPCD development process. The Port of Gothenburg, Sweden, became an important reference point, due to its early introduction of onshore power supply for regular passenger ferry and freight lines operating from the port and its use of renewable energy. Indeed, in the years since WPCl was launched, Gothenburg has received a number of awards and commendations for its work with OPS, such as a Global Energy Award in 2011 [50].

In recent years, Gothenburg and other WPCI ports have developed a highly-informative website on OPS and an increasing number of ports have introduced or plan to introduce OPS systems. Many of these ports are located on the West Coast of the USA, or in Europe (the Baltic and North Seas). These areas are all Emission Control Areas under MARPOL Annex VI Regulations for the Prevention of Air Pollution from Ships [51], suggesting that - despite the efforts of WPCI - regulations remain an important driver influencing adoption of OPS. Similarly, the EU and California have banned the use of heavy fuel oil in ports, and since November 2011, the EU has allowed Germany and Sweden to reduce the rate of electricity tax for electricity used in OPS systems [50]. Such measures have increased the cost-efficiency of using OPS in these contexts; yet OPS has not yet been widely adopted elsewhere.

\subsection{Analysis}

The WPCD represented a statement of responsibility and identified themes, approaches and actions to achieve lower emissions of greenhouse gases and air pollutants, and more generally, sustainable development in ports and at sea. To support implementation, the IAPH established the WPCl, a voluntary initiative which recognises and illustrates the need for interdisciplinary collaboration between stakeholders and across sectoral boundaries to

This is a pre-publication version. The final version of this article has the DOI:

10.1016/j.marpol.2015.12.012 and is available at:

http://www.sciencedirect.com/science/article/pii/S0308597X15003826 
reduce negative environmental impacts of shipping and related activities. As we have seen, WPCI has helped influence the adoption of new practices in some ports and by stakeholders, including shipping companies.

WPCI appears to focus more on particular parts of the WPCD (e.g. ocean-going shipping and terminal operations) whilst focusing less on other issues, such as hinterland transport and supply chains or renewable energy. Of course, this is not true for all participating ports, but rather a general observation concerning WPCl activities based on the available information about developments in the six years since WPCD. Moreover, the presence of first-mover problems (which influenced the origins of the process both in Rotterdam and the industry as a whole) meant the need for extensive engagement with diverse groups of stakeholders was noted already at the WPCD preparatory conference. Indeed, the Secretary-General of the International Maritime Organization commented upon this specific point in his speech to the World Ports Climate Conference [52]. The WPCD thus noted the need for individual and collective action and recommended approaches that avoid "one-size fits all" solutions or technological lock-in (an issue discussed in more detail in $[53,54,55]$ ).

In practice, although there are examples of individual and collective action, these appear to be concentrated in particular geographic clusters located in or around MARPOL Annex VI ECAs. It was, as recognised in the WPCD, always anticipated that some port authorities would be more engaged than others in WPCl. However, there appears to be a core group of active WPCI members, whilst others appear less engaged. This tends to reinforce the claims of Acuto [29] and indicate a "core-periphery" challenge facing the WPCl that is perhaps reflective of wider trends in the ports community. In other words, the active ports are not the many, but the few. If the climate and environmental impacts of shipping, both in ports and at sea, are to be comprehensively addressed, this needs to change and more ports need to be more active, both in WPCl and other contexts.

This outcome was considered a strong possibility during the development of WPCD. Indeed, it was partly for this reason that the WPCD's contents - and those of the WPCl - were broadranging. WPCD aimed to inspire a myriad of actions of varying scale, diversely spread across the globe, which when implemented - individually and collectively - would generate significant benefits in terms of reduced emissions, costs, etc. However, the WPCD was developed with the active involvement of cities and a TMN, and it was assumed that cities and TMNs would be actively involved in its implementation. $\mathrm{C} 40-\mathrm{CCl}$ would, it was assumed, play a role to facilitate partnerships and broker agreements with stakeholders, to help overcome some of the obstacles to collaborative or joint actions. Moreover, $\mathrm{C} 40-\mathrm{CCl}$ would encourage city-to-city exchanges and learning and disseminate information widely within and outside its networks.

This is a pre-publication version. The final version of this article has the DOI:

10.1016/j.marpol.2015.12.012 and is available at:

http://www.sciencedirect.com/science/article/pii/S0308597X15003826 
In practice, this does not appear to have occurred in a substantive manner. In the absence of C40-CCl or a similar TMN, the WPCl would itself have to assume a mediatory role and proactively engage cities and other stakeholders. This is somewhat problematic, not least because the WPCl (and some member ports) has limited resources (both in terms of resources or capacities) to engage in often extensive processes of consensus-building and co-development, but also because $\mathrm{C} 40-\mathrm{CCl}$ provided independent, cost-free services on a global basis with direct links to decision-making processes in the C40 cities. Without a TMN providing a link to cities and mediating engagement with other stakeholders, the WPCI has largely focused on using the WPCD as a platform to achieve transitions within shipping and port operations, that is to say, in and between individual ports and involving actors operating within the traditional ports and shipping industry.

Whilst this is understandable, the WPCD envisaged a wider process of engagement and action involving diverse groups of other stakeholders and addressing issues of wider scope (e.g. hinterland/inland/upstream transportation; energy systems; industries; and port-city integration). In other words, WPCD envisaged ports adopting a strategic approach to reducing greenhouse gas emissions and local air pollution, in order to enable deep and wide system changes both within the port, port-city and its surrounding regions, and also between ports across geographical divides.

This paper thus considers the WPCI to have achieved mixed results. A core group of active ports are taking positive steps and doing commendable work in particular geographic clusters. It is desirable that (a) more WPCI ports adopt these approaches and (b) more ports subscribe to the WPCD principles and actively work in WPCl. At the same time, there is significant potential for current WPCl ports to "unfold" their approaches and work strategically, by involving diverse groups of stakeholders in efforts to reduce emissions. There are examples of good practice concerning such work $[56,57]$ and opportunities to benefit from collaboration or synergies with other initiatives or projects $[58,59,60]$. New such initiatives are emerging, and sub-global governance structures are perceived as increasingly desirable [61,62].

\section{Discussion}

The WPCl is one of various initiatives aiming to reduce greenhouse gas emissions and other negative environmental impacts of maritime transport both at sea, in ports, port cities and their hinterlands. Such network governance initiatives appear to be essential and important processes in a world of multi-level governance. The WPCl recognises that ports have a responsibility to act, whilst accepting the need to work collaboratively both within and between sectors, as ports operate within the context of a wider economy and significant

This is a pre-publication version. The final version of this article has the DOI:

10.1016/j.marpol.2015.12.012 and is available at:

http://www.sciencedirect.com/science/article/pii/S0308597X15003826 
environmental impacts of shipping occur outside of the territorial boundaries of cities or even nations.

A series of interacting measures across multiple sectors is required and, in the current context, ports can be more creative in their use of the instruments they have (e.g. leasing agreements) and make use of frameworks such as WPCI to guide their strategic work to enable collaborations and synergies. Nonetheless, despite the potential to involve more ports and help stimulate a wider range of actions within WPCl, the absence of a strong and committed TMN, together with the relative invisibility of port cities, represent significant obstacles to implementation.

To date, there is little indication that cities have played a significant role in the implementation of WPCl, and the diffusion of knowledge, norms and practices in port cities as a result of WPCI is likely to be limited. This is striking, since the WPCD was initiated by a city and TMN working in collaboration with stakeholders from ports and shipping. The subsequent focus of the WPCl on the internal dynamics of the shipping industry represents a deviation from the approach discussed at the preparatory conference and agreed upon in the WPCD, which aimed towards comprehensive engagement with stakeholders. This change has almost certainly played a role in limiting the implementation of the WPCI.

A partial explanation is offered by Van Tatenhove et al., who show that when the resources and decision-making power of a governance structure are limited, and potential benefits uncertain, its capacity to work with stakeholders and governance performance is limited [63]. This is probably the case for the WPCl, and the presence of an active and committed TMN could potentially act as a catalyst to revive the WPCl, by increasing its resources to engage cities and contribute to improved integration of agendas and actions in port cities.

The typical functions of TMNs include diffusion of knowledge and practices, capacitybuilding, representation, policy evaluation and stimulating local action [13,21]. Each of these functions offers potential to help accelerate implementation of WPCI or similar initiatives, for example by supporting synergies or collaborations that increase the scope, scale or leverage of port cities' actions. Moreover, TMNs are considered to thrive in regional contexts where politically support is strong [25], implying there is potential to consolidate and diversify ports' work for sustainable development in the near future, particularly in and around MARPOL Annex VI ECAs. In the case of WPCI, C40 or a similar TMN could potentially increase its engagement and attempt to stimulate some currently inactive WPCD signatories to become more active.

TMNs may add value to municipal efforts to combat climate change and improve environmental conditions in urban areas. However, TMNs are not a panacea in themselves, but rather a platform for mediation and exchange which, if used effectively, may generate This is a pre-publication version. The final version of this article has the DOI:

10.1016/j.marpol.2015.12.012 and is available at:

http://www.sciencedirect.com/science/article/pii/S0308597X15003826 
positive outcomes. Having said that, TMNs are constituencies composed of, and to a large extent reflecting, the experiences of their members. TMNs face multiple challenges, not least with regards to capacities and resources, yet also in terms of issues such as their geographic and thematic coverage. Nevertheless, by acting as an intermediary and liaising with diverse groups of stakeholders, TMNs may be able to increase municipal organisations' awareness of other perspectives and transform them into participants in (rather than the owners of) local processes. This is important, because municipal organisations have multiple and varying roles, and may be leaders of or participants in processes, or control or be subject to the outcomes of processes; sometimes, such roles co-exist [17]. Similar statements may be made about ports, and given the natural links between ports and cities, increasing the levels of interaction and cooperation appear to offer obvious potential.

\section{Conclusions}

The case of the WPCI highlights some of the challenges concerning the current institutional arrangements for ports attempting to manage the climate and environmental impacts of shipping and other port operations. Based on the experiences of $\mathrm{WPCl}$, this paper argues that there is considerable potential to (a) increase links and synergies between existing initiatives within the ports sector; (b) increase the links and levels of coordination between port sector organisations such as IAPH, and TMNs such as C40 or ICLEI; (c) more actively engage cities in ports' strategic work for climate and environment; (d) systematically involve key stakeholders throughout processes (e.g. deeper involvement of cargo owners in ESI) to ensure maximum leverage of initiatives; and (e) increase the scope, range and number of activities aiming to reduce emissions from shipping-related activities on land and at sea.

Addressing these points will enable cities to play a more active and influential role in the maritime sector, and - through collaborative approaches - help ensure individual ports are not acting in isolation, but rather as part of a wider movement of regional or global port cities. Such a change could potentially add significant value to existing efforts of ports and/or port cities to reduce environmental and climate impacts arising directly from shipping, port operations and from related sectors, such as road freight transportation.

Of course, it is relatively easy to make such statements, yet much harder to translate words into sustained action. Although this paper highlights the potential for a more integrative, systemic interaction between ports and cities through or in partnership with TMNs, it should be noted that even though many port cities are currently active in TMNs, many TMNs have not addressed port issues in a structured way. Thus, there is considerable scope to improve the links between ports and cities, and thereby develop the role of cities and TMNs in reducing the climate and environmental impacts of shipping.

This is a pre-publication version. The final version of this article has the DOI:

10.1016/j.marpol.2015.12.012 and is available at:

http://www.sciencedirect.com/science/article/pii/S0308597X15003826 


\section{Acknowledgements}

I wish to thank the reviewers for their constructive input and the organisers and participants of the Shipping in Changing Climates conference for comments and suggestions.

\section{Glossary}

C40 - C40 Cities Climate Leadership Group

$\mathrm{CCl}$ - Clinton Climate Initiative

ECA - MARPOL Annex VI Emission Control Areas

ESI - Environmental Ship Index

IAPH - International Association of Ports and Harbours

ICLEI - International Council for Local Environmental Initiatives (ICLEI - Local Governments for Sustainability

OPS - Onshore Power Supply

$\mathrm{RCl}$ - Rotterdam Climate Initiative

TMNs - Transnational Municipal Networks

WPCD - World Ports Climate Declaration

WPCI - World Ports Climate Initiative

This is a pre-publication version. The final version of this article has the DOI:

10.1016/j.marpol.2015.12.012 and is available at:

http://www.sciencedirect.com/science/article/pii/S0308597X15003826 


\section{References}

[1] OECD. The Competitiveness of Global Port-Cities: Synthesis Report. Paris: OECD Publishing; 2013.

[2] Fusco Girard, L. Toward a Smart Sustainable Development of Port Cities/Areas: The Role of the "Historic Urban Landscape" Approach. Sustainability 2013; 5(10): 4329-4348.

DOI:10.3390/su5104329

[3] Jacobs, W, Ducruet, C, De Langen, PW. Integrating world cities into production networks: The case of port cities. Global Networks 2010; 10(1): 92-113. DOI: 10.1111/j.1471-0374.2010.00276.x

[4] Sassen, S. Global inter-city networks and commodity chains: any intersections? Global Networks 2010; 10(1): 150-163. DOI: 10.1111/j.1471-0374.2010.00279.x

[5] Inoue, S. Climate initiatives of the world's ports, pp. 225-40, in Asariotis, R, Benamara, H. (Eds.) Maritime Transport and the Climate Change Challenge, Oxford: Earthscan; 2012.

[6] PIANC, WG150 'Sustainable Ports' - A Guidance for Port Authorities. Brussels: PIANC; 2013. www1.iaphworldports.org/pdf/PIANC_WG150.pdf (last accessed 29 April 2015).

[7] Eyring, V, Isaksen, ISA, Berntsen, T, Collins, WJ, Corbett, JJ, Endresen, O, Grainger, RG, Moldanova, J, Schlager, H, Stevenson, DS. Transport impacts on atmosphere and climate: Shipping, Atmospheric Environment 2010; 44: 4735-4771. DOI:10.1016/j.atmosenv.2009.04.059

[8] OECD. Environmental Impacts of International Shipping: The Role of Ports. Paris: OECD Publishing; 2011.

[9] Smith, TWP., Day, S, Bucknall, R, Mangan, J, Dinwoodie. J, Landamore, M, Turan, O, Wrobel, P. Low Carbon Shipping - A Systems Approach, Final Report. 2013. www.lowcarbonshipping.co.uk (last accessed 29 April 2015).

[10] United Nations. Sustainable Development: From Brundtland to Rio 2012, Background Paper* prepared for consideration by the High Level Panel on Global Sustainability at its first meeting, 19 September 2010 www.un.org/wcm/webdav/site/climatechange/shared/gsp/docs/GSP1-

6_Background\%20on\%20Sustainable\%20Devt.pdf (last accessed 29 April 2015).

[11] United Nations Human Settlements Programme (UN-Habitat). Cities and Climate Change: Global report on human settlements 2011. London: Earthscan; 2011.

[12] Bulkeley, H, Castán Broto, V. Government by experiment? Global cities and the governing of climate change. Transactions of the Institute of British Geographers 2013; 38(3): 361-375.

DOI: $10.1111 / \mathrm{j} .1475-5661.2012 .00535 . x$

[13] Feldman, DL. The future of environmental networks-Governance and civil society in a global context, Futures 2012; 44: 787-796. DOI:10.1016/j.futures.2012.07.007

This is a pre-publication version. The final version of this article has the DOI:

10.1016/j.marpol.2015.12.012 and is available at:

http://www.sciencedirect.com/science/article/pii/S0308597X15003826 
[14] Rosenzweig, C, Solecki, WD, Hammer, SA, Mehrota, S. Executive Summary, pp. xv-xxiii in Rosenzweig, C, Solecki, WD, Hammer, SA, Mehrota, S, (Eds.) Climate Change and Cities: First Assessment Report of the Urban Climate Change Research Network. Cambridge: Cambridge University Press; 2011.

[15] Becker, A, Inoue, S, Fischer, M, Schwegler, B. Climate change impacts on international seaports: knowledge, perceptions, and planning efforts among port administrators. Climatic Change 2012; 110: 5-29. DOI: 10.1007/s10584-011-0043-7

[16] Betsill, M, Bulkeley, H. Looking Back and Thinking Ahead: A Decade of Cities and Climate Change Research. Local Environment: The International Journal of Justice and Sustainability 2007; 12(5): 447456. DOI: $10.1080 / 13549830701659683$

[17] Kern, K, Alber, G. Governing Climate Change in Cities: Modes of Urban Climate Governance in Multi-level Systems, pp. 171-196 in Competitive Cities and Climate Change, OECD Conference Proceedings, Milan, Italy, 9-10 October 2008. Paris: OECD; 2009.

[18] Niederhafner, S. Comparing functions of transnational city networks in Europe and Asia. Asia Europe Journal 2013; 11(4): 377-396. DOI: 10.1007/s10308-013-0365-3

[19] Kern, K, Bulkeley, H. Cities, Europeanization and multi-level governance: governing climate change through transnational municipal networks. Journal of Common Market Studies 2009; 47(2): 309-332. DOI: 10.1111/j.1468-5965.2009.00806.x

[20] Keiner, M, Kim, A. Transnational city networks for sustainability. European Planning Studies 2007; 15(10): 1369-1395. DOI: 10.1080/09654310701550843

[21] Bouteligier, S, Inequality in new global governance arrangements: the North-South divide in transnational municipal networks. Innovation: The European Journal of Social Science Research 2013; 26(3): 251-267. DOI: 10.1080/13511610.2013.771890

[22] Bulkeley, H, Davies, A, Evans, B, Gibbs, D, Kern, K, Theobald, K. Environmental Governance and Transnational Municipal Networks in Europe. Journal of Environmental Policy \& Planning 2003; 5(3): 235-254. DOI: 10.1080/1523908032000154179

[23] Román, M. Governing from the middle: the C40 Cities Leadership Group. Corporate Governance 2010; 10(1): 73-84. http://dx.doi.org/10.1108/14720701011021120

[24] Hakelberg, L. Governance by Diffusion: Transnational Municipal Networks and the Spread of Local Climate Strategies in Europe. Global Environmental Politics 2014; 14(1): 107-129.

DOI:10.1162/GLEP_a_00216

[25] Giest, S, Howlett, M. Comparative Climate Change Governance: Lessons from European Transnational Municipal Network Management Efforts. Environmental Policy and Governance 2013; 23(6): 341-353. DOI: 10.1002/eet.1628

This is a pre-publication version. The final version of this article has the DOI: 10.1016/j.marpol.2015.12.012 and is available at: http://www.sciencedirect.com/science/article/pii/S0308597X15003826 
[26] Aall, C, Groven, K, Lindseth, G. The scope of action for local climate policy: the case of Norway. Global Environmental Politics 2007; 7(2): 83-101. DOI:10.1162/glep.2007.7.2.83

[27] Fenton, P. Identifying the "Usual Suspects" - assessing patterns of representation in ICLEI case study collections. Linköping: Linköping University IEI Working Paper; 2014.

[28] ICLEI. Local Sustainability 2012: Taking stock and moving forward. Bonn: ICLEI; 2012.

[29] Acuto, M. The new climate leaders? Review of International Studies 2013; 39: 1-23. http://dx.doi.org/10.1017/\$0260210512000502

[30] McFarlane, C. The comparative city: knowledge, learning, urbanism. International Journal of Urban and Regional Research 2010; 34(4): 725-742. DOI: 10.1111/j.1468-2427.2010.00917.x

[31] Robinson, J. Cities in a World of Cities: The Comparative Gesture. International Journal of Urban and Regional Research 2011; 35: 1-23. DOI: 10.1111/j.1468-2427.2010.00982.x

[32] Ward, K. Towards a relational comparative approach to the study of cities. Progress in Human Geography 2010; 34(4): 471-487. DOI: 10.1177/0309132509350239

[33] Dolowitz, D, Keeley, M, Medearis, D. Stormwater management: can we learn from others? Policy Studies 2012; 33(6): 501-521. DOI: 10.1080/01442872.2012.722289

[34] Campbell, T. Learning cities: Knowledge, capacity and competitiveness. Habitat International 2009; 33(2): 195-201.

[35] Krause, RM. An Assessment of the Impact that Participation in Local Climate Networks Has on Cities' Implementation of Climate, Energy, and Transportation Policies. Review of Policy Research 2012; 29(5): 585-604. DOI: 10.1111/j.1541-1338.2012.00582.x

[36] Vellinga, T, de Jong, M. Approach to climate change adaptation in the Port of Rotterdam, pp. 305-319 in Asariotis, R, Benamara, H. (Eds.) Maritime Transport and the Climate Change Challenge, Oxford: Earthscan; 2012.

[37] Bouteligier, S. Cities, Networks, and Global Environmental Governance: Spaces of Innovation, Places of Leadership. London: Routledge, 2013.

[38] C40 Large Cities Climate Leadership Group, 2015. www.c40.org (last accessed 10 April 2015).

[39] Hoffmann, MJ. Climate governance experiments, pp. 235-248 in Dauverge, P. (Ed.) Handbook of Global Environmental Politics, Second Edition. Cheltenham: Edward Elgar, 2012.

[40] Sovacool, BK. Rising to the Challenge of Sustainability: Three Cases of Climate and Energy Governance, pp. 551-570 in Sioshansi, FP. (Ed.), Energy Sustainability and the Environment: Technology, Incentives, Behavior. New York: Elsevier, 2011.

This is a pre-publication version. The final version of this article has the DOI: 10.1016/j.marpol.2015.12.012 and is available at: http://www.sciencedirect.com/science/article/pii/S0308597X15003826 
[41] Bulkeley, H, Schroeder, H. Global cities and the politics of climate change, pp. 249-260 in Dauverge, P. (Ed.) Handbook of Global Environmental Politics, Second Edition. Cheltenham: Edward Elgar, 2012.

[42] Lee, T. Global Cities and Transnational Climate Change Networks, Global Environmental Politics 2013; 13(1): 108-128. DOI:10.1162/GLEP_a_00156

[43] Rotterdam Climate Initiative. The results of the Preparatory Conference for the C40 World Ports Climate Conference (final draft), 2007.

http://www.rotterdamclimateproof.com/documents/Documenten/RCI-English-WPCCdeclaration.pdf (last accessed 28 April 2015).

[44] World Ports Climate Initiative, wpci.iaphworldports.org (10 April 2015).

[45] World Ports Climate Initiative Environmental Ship Index Working Group, http://esi.wpci.nl/Public/Ships (last accessed 10 April 2015).

[46] BSR Clean Cargo Working Group http://www.bsr.org/en/collaboration/groups/clean-cargoworking-group (last accessed 10 April 2015).

[47] Lai, K-H, Luna, VYH, Wong, CWY, Chenga, TCE. Green shipping practices in the shipping industry: Conceptualization, adoption, and implications. Resources, Conservation and Recycling 2011; 55: 631638. DOI:10.1016/j.resconrec.2010.12.004

[48] Wuisan, L, van Leeuwen, J, van Koppen, CSA. Greening international shipping through private governance: A case study of the Clean Shipping Project. Marine Policy 2012; 36: 165-173.

DOI:10.1016/j.marpol.2011.04.009

[49] Gibbs, D, Rigot-Muller, P, Mangan, J, Lalwani, C. The role of seaports in end-to-end maritime transport chain emissions. Energy Policy 2014; 64: 337-348. DOI:10.1016/j.enpol.2013.09.024

[50] World Ports Climate Initiative Onshore Power Supply Working Group, http://www.ops.wpci.nl (last accessed 10 April 2015).

[51] International Maritime Organization, http://www.imo.org/OurWork/Environment/PollutionPrevention/AirPollution/Pages/AirPollution.aspx (last accessed 10 April 2015).

[52] Mitropoulos, EE. The contribution of IMO and shipping towards a cleaner and healthier atmosphere, Speech to World Ports Climate Conference, Rotterdam, 9 July 2008. http://www.imo.org/blast/mainframe.asp?topic_id=1698\&doc_id=9890 (accessed 28 April 2015).

[53] Kuznetsov, A, Dinwoodie, J, Gibbs, D, Sansom, M, Knowles, H. Towards a sustainability management system for smaller ports. Marine Policy 2015; 54: 59-68.

DOI:10.1016/j.marpol.2014.12.016

This is a pre-publication version. The final version of this article has the DOI: 10.1016/j.marpol.2015.12.012 and is available at: http://www.sciencedirect.com/science/article/pii/S0308597X15003826 
[54] Gilbert, P. From reductionism to systems thinking: How the shipping sector can address sulphur regulation and tackle climate change. Marine Policy 2014; 43: 376-378.

DOI:10.1016/j.marpol.2013.07.009

[55] Corvellec, H, Zapata Campos, MJ, Zapata, P. Infrastructures, lock-in, and sustainable urban development: the case of waste incineration in the Göteborg Metropolitan Area. Journal of Cleaner Production 2013; 50: 32-39. DOI:10.1016/j.jclepro.2012.12.009

[56] European Sea Ports Organisation ESPO Green Guide - Annex 1: Good practice examples in line with the 5 Es. Brussels: ESPO, 2013.

[57] Federation Nationale des Agences d'Urbanisme (FNAU). Innovations Ville-Port - pour des projets intégrés Ville-Port. Paris: FNAU, 2011.

[58] PPCAC, Pacific Ports Clean Air Collaborative, www.ppcac.org (last accessed 10 April 2015).

[59] RETE, Association for the Collaboration between Ports and Cities, http://retedigital.com/en (last accessed 10 April 2015).

[60] EPIC Project (Symbiotic bio-Energy Port Integration with Cities by 2020), www.epic2020.eu (last accessed 10 April 2015).

[61] EPA, Port Stakeholders Summit: Advancing More Sustainable Ports (April 2014), http://www2.epa.gov/ports-initiative/port-stakeholder-summit-april-2014 (last accessed 10 April 2015)

[62] Gilbert, P, Bows, A. Exploring the scope for complementary sub-global policy to mitigate $\mathrm{CO} 2$ from shipping. Energy Policy 2012; 50: 613-622. DOI: 10.1016/j.enpol.2012.08.002

[63] van Tatenhove, J, Raakjaer, J, van Leeuwen, J, van Hoof, L. Regional cooperation for European seas: Governance models in support of the implementation of the MSFD. Marine Policy 2014; 50; 364-372. DOI: 10.1016/j.marpol.2014.02.020

This is a pre-publication version. The final version of this article has the DOI:

10.1016/j.marpol.2015.12.012 and is available at:

http://www.sciencedirect.com/science/article/pii/S0308597X15003826 